\title{
HISTORY OF THE JEWISH INTERPRETATION OF GENESIS 1:26, 3:5, 3:22 IN THE MIDDLE AGES
}

\author{
Matthew Oseka \\ Concordia Theological Seminary \\ Hong Kong
}

\begin{abstract}
The present article analyses the plural forms occurring in Genesis 1:26, 3:5 and 3:22 which might appertain to God and which acted as focal points for theological and exegetical discussion within the framework of the Jewish tradition. Furthermore, the article studies the mediaeval Jewish exegesis of these forms as recorded in the representative Jewish commentaries and situates it against the early Jewish reception of these forms.
\end{abstract}

Key Words: Genesis 1:26; 3:5; 3:22; Hebrew Studies; Jewish Studies; Hebrew Scriptures; Mediaeval Jewish Exegesis

\section{Introduction}

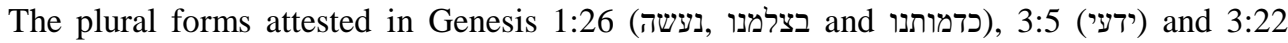
(כאחד ממנו), which might relate to God, were discussed within the framework of the Jewish tradition. The canonical form of Genesis 1-3 was the final result of a long process in which strata of various traditions were interacting with each other until they solidified into the document which was received and transmitted as canonical. Notwithstanding a complex history of redaction which can be reconstructed only partially, the ultimate text of the narratives found in Genesis 1-3 seems to be coherent in literary terms and thus, the aforementioned plural forms that occur in Genesis 1:26, 3:5, 3:22 might be studied together. Naturally, there were also other passages in the Tanakh such as Genesis 11:7 (נרדה ונבלה), 20:13 (נגלו) which contained the plural forms potentially referring to God but these passages could not be reviewed in the present article.

Since the mediaeval Jewish exegesis of these forms drew upon the early Jewish interpretation, which was recorded in the ancient Aramaic and Greek translations of the Scripture and reflected in the Midrashic and Talmudic literature, the present article also examines this hermeneutical root of the Jewish exposition of these phenomena. Although the dating of the Targumim and Midrashim is debatable, the author of the present article does not presume that this ancient Jewish literature was created primarily to combat emerging forms of early Christian theology. ${ }^{1}$ Rather, this corpus aimed to preserve and to elucidate the Jewish tradition in the face of the profound challenges to which Judaism needed to respond in that period.

Comments on the plural forms made by Philo of Alexandria ${ }^{2}$ were intentionally excluded from the present enquiry though they demonstrated that such forms challenged

Cf. Johann Cook, “Anti-heretical Traditions in Targum Pseudo-Jonathan,” Journal of Northwest Semitic Languages 11, 1983:47-57.

2 Philo Alexandrinus, "De opificio mundi," in Opera quae supersunt, vol. 1, (ed.) Leopold Cohn and Paul Wendland (Berlin: Reimer, 1896), 24-25 [24, 72-76]. Ibidem, 46-47 [46, 134-135]. Idem, "Legum allegoriarum liber III," in Opera, vol. 1, 134 [31, 96]. Idem, "De confusione linguarum," in Opera quae 
ancient Jewish literati. In addition, the relationship between the Philonic legacy and the Rabbinic tradition is complex ${ }^{3}$ and cannot be scrutinised in the present essay.

Historical-critical commentaries on the Book of Genesis ${ }^{4}$ and particular studies ${ }^{5}$ analysed the forms in question but none of them intended to be a history of their Jewish elucidation in the Middle Ages. Generally speaking, the findings of modern interpreters coincided with the propositions which emerged in the Jewish reading of the Tanakh. It should be noted that the literature on the generic name of $\operatorname{God}^{6}$ is immense, while the plural forms in Genesis 1:26 cannot be interpreted apart from the question of what was meant by the image and likeness in which humankind was made according to the biblical narrative. ${ }^{7}$

supersunt, vol. 2, (ed.) Cohn and Wendland (Berlin: Reimer, 1897), 261 [33, 169]. Ibidem, 263-264 [34-36, 175-182]. Idem, "Quis rerum divinarum heres sit," in Opera quae supersunt, vol. 3, (ed.) Cohn and Wendland (Berlin: Reimer, 1898), 38 [34, 165-167]. Idem, "De fuga et inventione," in Opera, vol. 3, 124-125 [13-14, 66-76]. Idem, "De mutatione nominum," in Opera, vol. 3, 161-163 [4, 27-38]. Idem, "De sominiis liber I," in Opera, vol. 3, 239-240 [26, 160-165]. Idem, "In Genesi: Sermo I," in Paralipomena Armena, (ed.) Joannes Baptista Aucher (Venice: Lazari, 1826), 25-26 [XXXVI]. Ibidem, 36-37 [LIV].

3 Maren R Niehoff, "Questions and Answers in Philo and Genesis Rabbah," Journal for the Study of Judaism 39, 2008:337-366. AJM Wedderburn, "Philo's >Heavenly Man<," Novum Testamentum 15, no. 4, 1973:301-326.

4 August Dillmann, Genesis Critically and Exegetically Expounded, vol. 1, trans. William Black Stevenson (Edinburgh: Clark, 1897), 77-85 [Genesis 1:26-27]. Ibidem, 151-152 [Genesis 3:5]. Ibidem, 167-169 [Genesis 3:22]. Samuel Rolles Driver, The Book of Genesis with Introduction and Notes (London: Methuen, 1904), 14-15 [Genesis 1:26-27]. Ibidem, 45 [Genesis 3:5]. Ibidem, 50 [Genesis 3:22]. Carl Friedrich Keil and Franz Delitzsch, Biblical Commentary on the Old Testament, vol. 1, trans. James Martin (Grand Rapids: Eerdmans, [s. a.]), 61-67 [Genesis 1:24-31]. Ibidem, 94-96 [Genesis 3:1-8]. Ibidem, 106-108 [Genesis 3:22]. Gerhard von Rad, Genesis: A Commentary, trans. John H. Marks (Philadelphia: The Westminster Press, 1961), 55-59 [Genesis 1:26-28]. Ibidem, 86-87 [Genesis 3:4-5]. Ibidem, 94 [Genesis 3:22]. Gordon J Wenham, Genesis: 1-15, vol. 1 (Dallas: Word, 1998), 27-34 [Genesis 1:26-28]. Ibidem, 73-75 [Genesis 3:5]. Ibidem, 85 [Genesis 3:22]. Claus Westermann, Genesis 1-11: A Commentary, trans. John J Scullion (Minneapolis: Augsburg Publishing House, 1984), 142-161 [Genesis 1:26-28]. Ibidem, 240-248 [Genesis 3:5]. Ibidem, 272-273 [Genesis 3:22].

5 Ryan S Dulkin, “The Triumph of Mercy: An Ethical-Critical Reading of Rabbinic Expansions on the Narrative of Humanity's Creation in Genesis Rabbah 8," Journal of the Society of Christian Ethics 33, no. 1, 2013:139-151. Jarl Fossum, "Gen. 1:26 and 2:7 in Judaism, Samaritanism and Gnosticism," Journal for the Study of Judaism 16, no. 2, 1985:202-239. Gerhard F Hasel, "The Meaning of >Let us< in Gen. 1:26," Andrews University Seminary Studies 13, no. 1, 1975:58-66.

6 Joel S Burnett, A Reassessment of Biblical Elohim (Atlanta: Society of Biblical Literature, 2001). NA Dahl and Alan F Segal, "Philo and the Rabbis on the Names of God," Journal for the Study of Judaism 9, no. 1, 1978:1-28. Anne E Draffkorn, "Ilani/Elohim," Journal of Biblical Literature 76, no. 3, 1957:216-224. Cyrus Herzl Gordon, "אלהים in its Reputed Meaning of >Rulers<, > Judges<," Journal of Biblical Literature 54, no. 3, 1935:139-144. Murray J Harris, “The Translation of Elohim in Psalm 45:7-8," Tyndale Bulletin 35, 1984:65-89. Michael S Heiser, "Deuteronomy 32:8 and the Sons of God," Bibliotheca Sacra 158, no. 629, 2001:52-74. Jan Joosten, “A Note on the Text of Deuteronomy 32:8," Vetus Testamentum 57, no. 4 2007:548555. John L McKenzie, "The Appellative Use of El and Elohim," The Catholic Biblical Quarterly 10, no. 2, 1948:170-181. Helmer Ringgren, 'אלהים,' in Theological Dictionary of the Old Testament, vol. 1, (ed.) Gerhard Johannes Botterweck and Helmer Ringgren, trans. John T Willis (Grand Rapids: Eerdmans, 1974), 267-284. Terrance Randall Wardlaw, Conceptualising Words for > God< within the Pentateuch: A Cognitive-Semantic Investigation in Literary Context (New York: Clark, 2008).

7 Gerald Bray, "The Significance of God's Image in Man," Tyndale Bulletin 42/2, 1991:195-225.

David JA Clines, "The Image of God in Man," Tyndale Bulletin 19, 1968:53-103. Carly Lorraine Crouch, "Genesis 1:26-7 as a Statement of Humanity's Divine Parentage," Journal of Theological Studies 61/1, 2010:1-15. Paul Niskanen, "The Poetics of Adam: The Creation of אדם ine Image of the Journal of Biblical Literature 128, no. 3, 2009:417-436. Claudia Welz, "Imago Dei: References to the Invisible," Studia Theologica 65, 2011:74-91. 


\section{Textual Study and Ancient Translations}

The Hebrew text of Genesis 1:26, 3:5 and 3:22 was uniform in the Masoretic and Samaritan $^{8}$ versions as far as the plural forms are concerned. From a literary perspective, in

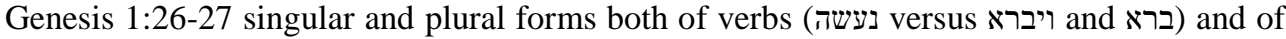
pronominal suffixes (בצלמנו and בצמו visu versus were used interchangeably. In view of the parallelism, בצלמנו from Genesis 1:26 should be explicated in the light of בצלם אלהנו from Genesis 1:27. Thus, "our image", in which human beings were created, was that of אלהים. In the narrative there is also a natural transition from the singular to the plural concerning אדם that could denote either the individual person distinct from Eve and called Adam or both male (זכר) and female (נקבה) as indicated by Genesis 1:27. Therefore, in Genesis 1:26a God said "let us make אדם [...]" but in Genesis 1:26b God said with reference to אדם "let them rule (וירדו) [...]".

The Targum Onkelos ${ }^{9}$ upheld the plural form of the verb in Genesis 1:26a, rendering נעשה Hebrew נעביד Actually, in Hebrew verbs עשה and עבד could be synonyms. Furthermore, in the Targum Onkelos to Genesis 1:26 the plural pronominal suffixes on דמות wלם דמ דמ were retained, while the Aramaic equivalents of both nouns were used with the same prepositions ( $ב$ and $\supset$, respectively). The Targum Pseudo-Jonathan ${ }^{10}$ followed the interpretation found in the Targum Onkelos, yet it elucidated Genesis 1:26 in theological terms by adding that God said "let us make [...]" to the angels that were created by him and that were ministering in front of him. Moreover, the Targum Pseudo-Jonathan used the Aramaic noun (דיוקננא) of Greek origin $\left(\delta v_{0}+\varepsilon i \kappa \omega ́ v\right)^{11}$ in place of דמות which could function both in Hebrew and in Aramaic and which was employed by the Targum Onkelos. Besides, the Targum to Psalm 39:7a translated צלם as דיוקנא. The Furthermore, in the Targum Pseudo-Jonathan the preposition כ, which occurs with דמות both in the Hebrew original and in the Targum Onkelos, is replaced with the Aramaic preposition ב. Thus, it

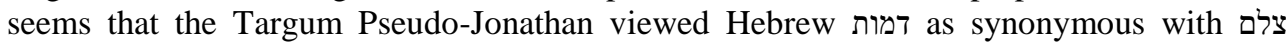
בדיוקננא was appositive to בצלמנא.

Although no Jerusalem Targum to Genesis 1:26 is extant, the Jerusalem Targum to Genesis 1:27 casts light upon the preceding verse. ${ }^{13}$ Accordingly, the act of creating human beings was attributed to the Word of the LORD (מימרא דיי), while human beings were created in the likeness (דמות) of the Word of the LORD, namely, in the "likeness from before the LORD". Such an interpretation articulated that the LORD used his Word as the instrument mediating between the intangible and the tangible, while creating the world and while acting in the created realm. This approach coincided with the Philonic concept of $\lambda$ ó $\gamma$ ऽ and it could be traced back to the biblical literature (e.g. Jeremiah 10:12; Psalm 33:6; Proverbs 3:19, chapter 8 or Job 28) which recorded the idea of God's Wisdom

August von Gall, (ed.), Der Hebräische Pentateuch der Samaritaner, vol. 1 (Giessen: Töpelmann, 1914), 1 [Genesis 1:26]. Ibidem, 4 [Genesis 3:5]. Ibidem, 5 [Genesis 3:22].

Abraham Berliner, (ed.), Targum Onkelos, vol. 1 (Berlin: Kauffmann, 1884), 2 [Genesis 1:26].

10 "Targum [Pseudo-]Jonathan," in Biblia sacra polyglotta, vol. 4, (ed.) Brian Walton (London: Roycroft, 1657),

3 [Genesis 1:26]. Collated with: Ernest George Clarke, (ed.), Targum Pseudo-Jonathan of the Pentateuch:

Text and Concordance (Hoboken: KTAV, 1984), 2 [Genesis 1:26].

11 Nathan Jehiel, Rabbinisch-aramäisch-deutsches Wörterbuch zur Kenntnis des Talmuds, der Targumim und Midraschim, vol. 2, (ed.) Moses Israel Landau (Prague: Scholl, 1819), 461-462 [s. v. דיוקן]. Jacob Levy, Chaldäisches Wörterbuch über die Targumim und einen grossen Teil des rabbinischen Schrifttums, vol. 1 (Leipzig: Baumgärtner, 1867), 170 [s.v. דיוקנ]].

12 “Targum," in Biblia sacra polyglotta, vol. 3, (ed.) Walton (London: Roycroft, 1656), 144 [Psalm 39:7].

13 "Targum Hierosolymitanum," in Biblia sacra polyglotta, vol. 4, 3 [Genesis 1:27]. 


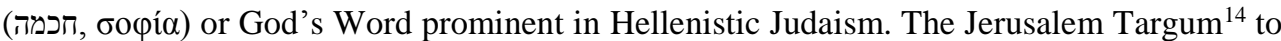
Genesis 1:1 and the tractate Sanhedrin ${ }^{15}$ maintained that God created the universe through (ב) the Wisdom (בכמה), whereas the grand Midrash on the Book of Genesis ${ }^{16}$ (בראשית רבה) announced that while looking at the Torah (מביט בתורה), God created the universe because ראשית, by means of which (ב) God was said to create the world, was identified with the Torah. Similarly, the Pirke attributed to Rabbi Eliezer ${ }^{17}$ asserted that God said "let us make [...]", conversing with the Torah about his anticipated act of creating human beings. Consequently, the divine Wisdom (identical with the Torah) was construed as the LORD's instrument (כלי אומנותו של דקב"ה), as the agency which emanated from God and which represented God, yet without being independent of God in ontological terms. The Yalkut Shimoni ${ }^{18}$ suggested that God might say "let us make [...]" either to the Torah or to the angels serving in front of him.

The ancient Greek versions of Genesis 1:26 preserved all plural features of the Hebrew

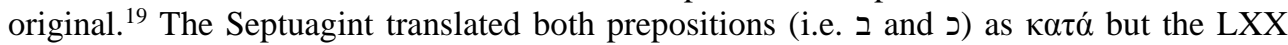
revisions offered a more nuanced rendition. Aquila and Theodotion interpreted with בלם as $\dot{\varepsilon} v$ ("in our image"), while Symmachus rendered it as $\dot{\omega} \zeta$ ("as our image"). The

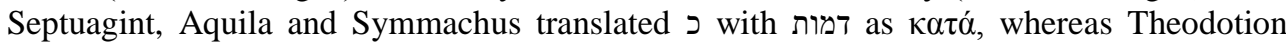
resorted to $\dot{\omega} s$.

It is notable that a parallelism found in the Book of Sirach, which was a part of the Septuagint, illustrated how the image in which human beings were created, was understood in that Hellenistic Jewish text. In the light of the Book of Sirach $(17: 3)^{20}$ the statement, that

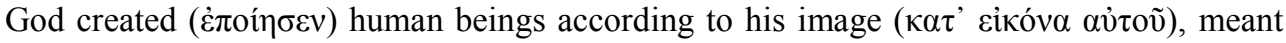

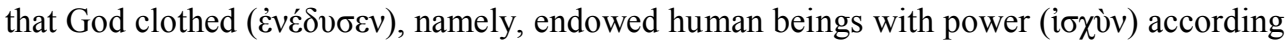
to himself ( $\kappa \alpha \theta^{\prime} \dot{\varepsilon} \alpha v \tau$ òv). Thus, the creation in accordance with God's image was the creation on the pattern of God himself, while this pattern conveyed a sense of divine power.

In the narrative Genesis 3:5 and Genesis 3:22 were interrelated because in the former passage the serpent enticed Eve to eat the fruit by saying that in consequence she and Adam would be like אלהים (כ) knowing (ידעי) good and evil, whereas in the latter passage God ( "כחוב)

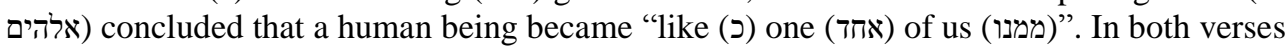
there were plural forms (ידעי) or phrases (כאחד ממנו) potentially pertinent to God.

The Targum Onkelos ${ }^{21}$ and the Targum Pseudo-Jonathan ${ }^{22}$ reworked Genesis 3:5 in order to streamline the narrative from the theological point of view. The explicit statement, that "God knows [...]" (ידע אלהים), which in the original was attributed to the serpent, was rephrased to ensure the serpent's distance from God. Thus, the Targumim read that the

14 Ibidem, 2 [Genesis 1:1]. See the reference to Proverbs 3:19:בער מדרש תנחומא in "בראשית,"Petrikau: צפרבוים, 1913), 1 [Genesis 1:1].

15 "תלמוד בבלי "ספנהדרית, vol. 13 (Warsaw: Orgelbrand, 1862), 38r [no. 38a].

16 מדרש רבה על התורה (Warsaw: Orgelbrand, 1890), 1r [I, 2 (Genesis 1:1)].

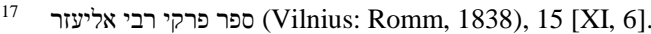

18 ספר ילקוט שמעוני (Vilnius: Romm, 1863), 6r-6v [no. 12-14 (Genesis 1:26)].

19 Henry Barclay Swete, (ed.), The Old Testament in Greek according to the Septuagint, vol. 1 (Cambridge:

Cambridge University Press, 1887), 2 [Genesis 1:26]. Frederick Field, (ed.), Origenis Hexaplorum quae supersunt: Sive veterum interpretum Graecorum in totum Vetus Testamentum fragmenta, vol. 1 (Oxford: Clarendon, 1875), 10 [Genesis 1:26 (Aquila, Symmachus and Theodotion)].

20 Robert Holmes and James Parsons, (ed.), Vetus Testamentum Graecum cum variis lectionibus, vol. 5

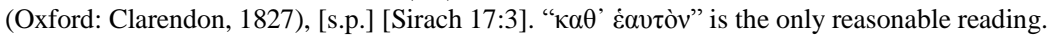

21 Berliner, (ed.), Targum, vol. 1, 3 [Genesis 3:5].

22 "Targum [Pseudo-]Jonathan," 5 [Genesis 3:5]. Clarke, (ed.), Targum Pseudo-Jonathan of the Pentateuch, 3 [Genesis 3:5]. 
serpent said to Eve: "it was evident in front of the LORD that [...]". Moreover, according to the Targum Onkelos, the serpent encouraged Eve to eat the fruit so that she and Adam would be like (כ) "the mighty" (רברבין) who knew the difference between (בין) good and evil. The Targum Pseudo-Jonathan coincided with the Targum Onkelos, yet specified that "the mighty" (רברבין) were the mighty angels (מלאכין) because the appellation רברבין was so generic that it might refer to any kind of human or angelic beings vested with authority and power. Additionally, both Targumim stated that "the mighty/angels" knew the difference between (בין) good and evil instead of saying that they simply knew good and evil because the direct knowledge of good and evil was reserved for God.

The Septuagint ${ }^{23}$ translated Genesis 3:5 literally, asserting that by eating the fruit, Adam and Eve were supposed to be "like gods" ( $\dot{\zeta} \theta \varepsilon \circ$ oí) who knew ( $\gamma \imath \omega \dot{\omega} \sigma \kappa o v \tau \varepsilon \varsigma)$ good and evil. Consequently, it appears that the plural form of the participle (ידעי) in the Hebrew original of Genesis 3:5b impelled the LXX translators to parse אלהים in that verse as plural.

The Masoretic text of Genesis 3:22 and the Septuagint ${ }^{24}$ dovetailed together. The LXX imitated literally both the plural phrasing ( $\dot{\omega} \varsigma \varepsilon \tilde{\varepsilon} \zeta \dot{\varepsilon} \xi \dot{\eta} \mu \tilde{\omega} v)$ [כאחד ממנו] and the purpose clause ( Targum Onkelos ${ }^{26}$ the Targum Pseudo-Jonathan ${ }^{27}$ and the Jerusalem Targum ${ }^{28}$ proposed complex interpretations which could be visualised as follows:

\begin{tabular}{|c|c|c|c|}
\hline Symmachus & Onkelos & Pseudo-Jonathan & Jerusalem \\
\hline - & ואמר יי אלהים & ואמר יי אלהים & ואמר מימרא דיי אלהים \\
\hline and God said & $\begin{array}{l}\text { and the LORD } \\
\text { God said }\end{array}$ & $\begin{array}{l}\text { and the LORD God } \\
\text { said }\end{array}$ & $\begin{array}{l}\text { and the Word of the } \\
\text { LORD-God said }\end{array}$ \\
\hline- & - & קדמלאכיא די משמשין & - \\
\hline- & - & $\begin{array}{l}\text { to the angels } \\
\text { ministering in front } \\
\text { of him }\end{array}$ & - \\
\hline 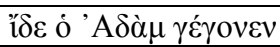 & הא אדם הוה & הא אדם הוה & הא אדם דברית יתיה \\
\hline $\begin{array}{l}\text { Behold, } \\
\text { Adam became }\end{array}$ & $\begin{array}{l}\text { Behold, } \\
\text { Adam became }\end{array}$ & $\begin{array}{l}\text { Behold, } \\
\text { Adam became }\end{array}$ & $\begin{array}{l}\text { Behold, } \\
\text { Adam whom I created }\end{array}$ \\
\hline$\dot{\alpha} \mu o \tilde{v} \alpha \varphi^{\prime} \dot{\varepsilon} \alpha v \tau o v \tilde{v}$ & יחידי בעלמא מיניה & יחידיי בארעא היכמא & יחידי בגו עלמי היך מה \\
\hline just by himself & $\begin{array}{l}\text { unique in the world } \\
\text { by himself/on his } \\
\text { own }\end{array}$ & unique on earth as & $\begin{array}{l}\text { unique in my world } \\
\text { just as }\end{array}$ \\
\hline- & - & דאנא יחידי בשמי מרומא & דאנא יחידי בשמי מרומא \\
\hline - & - & $\begin{array}{l}\text { I am unique in the } \\
\text { heaven above }\end{array}$ & $\begin{array}{l}\text { I am unique in the } \\
\text { heaven above }\end{array}$ \\
\hline- & - & ועתידין & ועתידין \\
\hline
\end{tabular}

23 Swete, (ed.), The Old Testament, vol. 1, 4 [Genesis 3:5].

24 Ibidem, 5 [Genesis 3:22].

25 Field, (ed.), Origenis Hexaplorum, vol. 1, 17 [Genesis 3:22 (Symmachus)].

26 Berliner, (ed.), Targum, vol. 1, 4 [Genesis 3:22].

27 “Targum [Pseudo-]Jonathan," 7 [Genesis 3:22]. Clarke, (ed.), Targum Pseudo-Jonathan of the Pentateuch, 4 [Genesis 3:22]. "Targum of Palestine," in The Targums of Onkelos and Jonathan ben Uzziel on the

Pentateuch with the Fragments of the Jerusalem Targum: Genesis and Exodus, trans. John Wesley Etheridge (London: Longman, 1862), 168 [Genesis 3:22].

28 "Targum Hierosolymitanum," 7 [Genesis 3:22]. "Jerusalem," in The Targums, 169 [Genesis 3:22]. 


\begin{tabular}{|c|c|c|c|}
\hline- & - & and in the future & and in the future \\
\hline- & - & למיקום מניה & אומין סגיאין למקם מניה \\
\hline- & - & arise from him & $\begin{array}{l}\text { arise from him the } \\
\text { numerous people }\end{array}$ \\
\hline - & - & - & מניה תקום אומה \\
\hline- & - & - & $\begin{array}{l}\text { from him arise the } \\
\text { people }\end{array}$ \\
\hline 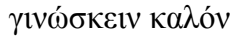 & למידע טב & דידעין למפרשא בין טב & דידעה למפרשא בין טב \\
\hline to know good & to know good & $\begin{array}{l}\text { those who know } \\
\text { how to discern } \\
\text { between good }\end{array}$ & $\begin{array}{l}\text { who know } \\
\text { how to discern } \\
\text { between good }\end{array}$ \\
\hline 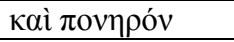 & וביש & לביש & לביש \\
\hline and evil & and evil & and evil & and evil \\
\hline- & - & $\begin{array}{l}\text { "Had he kept the } \\
\text { commandments } \\
\text { which I appointed to } \\
\text { him, he would have } \\
\text { lived and subsisted } \\
\text { as the tree of life } \\
\text { forever [...]." }\end{array}$ & $\begin{array}{l}\text { "And now it is good } \\
\text { that we keep [דנטרוד] } \\
\text { him from the garden of } \\
\text { Eden [...]." }\end{array}$ \\
\hline
\end{tabular}

In principle, the interpretations cited above were seamless from a theological perspective because God did not say that Adam became כאחד ממנו but rather depicted Adam as unique (יחידי) in the world due to his ability to discern between good and evil. From Genesis 3:5 it appears that Adam acquired this ability by eating the fruit. Consequently, the Targum Pseudo-Jonathan and the Jerusalem Targum compared this unique position of Adam in the world to God's unique position in the heaven.

It seems that all the Targumim relied on the same grammatical presuppositions concerning the original text of Genesis 3:22 which might be reconstructed as follows. Firstly, אחד was construed as the absolute state and it was said to denote 'unique'. Secondly, אחד was linked to the infinitive (לדעת). Thus, Adam either individually (as Adam) or collectively (as Adam's posterity) ${ }^{29}$ became like the one who was to know good and evil. Thirdly, the preposition with the pronominal suffix (ממנו) was parsed as singular ("from him", "on his own", "by himself") ${ }^{30}$ and it modified either the infinitive (לדעת) or the verb (היה). Consequently, Adam became like the one who was to know good and evil, and either in this condition (היה) or in this knowledge (לדעת) Adam was self-reliant (ממנו) in the world. In other words, either Adam became by himself like the one who was to know good and evil, or Adam became like the one who was to know by himself good and evil. It should be noted that in Symmachus' revision ( $\left.\alpha \varphi^{\prime} \dot{\varepsilon} \alpha v \tau o \tilde{v}\right)$ ממנו was interpreted in the same way as in the Targumim, while Greek ó $\mu$ õ might imply that Symmachus' revision took כאחד for the

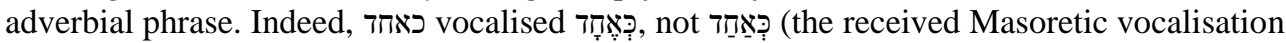
in Genesis 3:22), acted as the adverbial phrase denoting "together, totally or at once" in the Tanakh (2 Chronicles 5:13; Ezra 2:64, 3:9, 6:20; Nehemiah 7:66; Ecclesiastes 11:6; Isaiah $65: 25)$. 
Furthermore, the Targum Pseudo-Jonathan and the Jerusalem Targum mentioned that Adam as a prototype of humankind would originate countless future generations of human beings who could discern between good and evil. To emphasise that the direct knowledge of good and evil was reserved for God, both Targumim preferred to speak of "knowing how to discern between good and evil," which indicated that human beings could discern between these two but not necessarily penetrate them. Although the Jerusalem Targum facilitated the exposition of Genesis 3:22, it also attributed a new plural form (נטרוד) to God who referred to his own action in the plural ("we keep/let us keep"). Given that this new plural form did not occur in the Hebrew original, it might be an imitation of נעשה from Genesis 1:26. Thus, in the act of creation God said "let us make a human [...]", while in response to Adam's action, God said "let us keep a human away from the garden [...]".

\section{References in the Midrashic and Talmudic Literature}

Expounding Genesis 1:1, the grand Midrash on the Book of Genesis ${ }^{31}$ safeguarded the unity of God and pointed out that אלהים, which could be parsed either as singular or as plural and which might denote either true/false God(s) or human/angelic agent(s) of power, depending on the context, referred to the one and only God in Genesis 1:1 because אלהים acted as the subject of the singular verb (ברא), not the plural one (בראו). Likewise, the grand Midrash ${ }^{32}$ recalled that Genesis 1:27 read that God created (ויברא אלהים), not that gods created (רים ויבראו) אלהים), humankind. Thus, there was only one divine authority/power (רשות), not many (רשויות), creating the universe. This hermeneutical presupposition determined the Midrashic interpretation of the plural forms which in Genesis 1-3 might refer to God.

Commenting upon Genesis 1:26, the grand Midrash ${ }^{33}$ contended that the plural form "let us make [...]" signalled that God consulted (נמלך) someone or something, while creating the human race. Several answers to the question, whom God consulted, were recorded in the grand Midrash. According to the first interpretation, God consulted (נמלך) the works of heaven and earth, namely, the intangible ${ }^{34}$ and tangible ${ }^{35}$ creatures which were created prior to the creation of humankind. The grand Midrash mentioned that God could either consult all pre-human creatures at once or could consult creatures made on every single day prior to the creation of human beings. This process of consultation was compared to a political situation in which a king would not act without seeking advice from his counsellors.

According to the second interpretation, God consulted his own heart, namely, consulted himself while creating humankind because when human conduct disappointed God, in Genesis 6:6 God did not blame any proxy or contractor engaged in the work of creation but rather the LORD himself regretted creating human beings and the LORD himself held his own heart (אל לבו) accountable for the act of creation. According to the third interpretation, which was tinged with Platonising colour, God consulted preexisting souls of the righteous.

According to the fourth interpretation, God consulted the angels ministering in front of

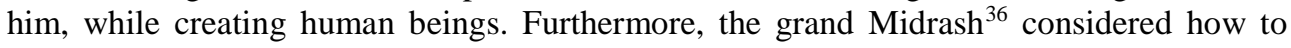
explicate God's consultation with angels in the light of the LORD's sovereignty, because

\footnotetext{
31 "מדרש רבה על התורה in, 2v [I, 10 (Genesis 1:1)].

32 Ibidem, 16r [VIII, 8 (Genesis 1:26)].

33 Ibidem, 15r-16r [VIII, 3-7 (Genesis 1:26)]. Ibidem, 29v [XIV, 3 (Genesis 2:7)].

34 Thus, angels were included.

35 Animate and inanimate.

36 "מדרש רבה על התורה in, 15v-16r [VIII, 7 (Genesis 1:26)].
} 
God was said to seek advice from beings (angels, to be precise) that were created by him and that were inferior and subordinate to him, albeit it would not be customary for superiors to seek advice from their inferiors. Therefore, the grand Midrash viewed God's consultation with angels as a token of the LORD's benevolence and humility, and clarified that while consulting angels, God did not ask for their permission to create humankind but rather requested their opinion without compromising his own authority and power to do whatever would please him.

As regards the creation of human beings in God's image, the grand Midrash ${ }^{37}$ registered that the human race was created as a bridge between "upper" beings and "lower" beings, namely, between spiritual beings (i.e. God along with his angels) ${ }^{38}$ and animals. Consequently, humankind would embrace both intellectual and physical attributes, and would be torn between immortality characteristic of the spiritual sphere, and mortality intrinsic to the physical sphere. Thus, human beings were created, on the one hand, in the image and likeness coming from the upper realm (מן העליונים), and on the other hand, in the image and likeness arising from the lower realm (מן התחתונים). In short, they were created as both intangible and tangible beings. The upper sphere, which might be called spiritual, intellecttual or celestial, knew neither reproduction nor death, while the lower sphere, which could be denominated as physical, animal or earthly, harboured both of these phenomena. ${ }^{39}$

Therefore, it could be argued that according to the grand Midrash, the image, which God imprinted on human beings, consisted in both intangible and tangible features by virtue of which humankind could act as a bridge between heaven and earth. Thus, the image referred to in Genesis 1:26-27 was God's in the sense that God was the One who imprinted the image. In other words, the image, in which human beings were created, was that of God because God intentionally designed human identity to bridge both dimensions. This idea was adopted by the subsequent Jewish literature. ${ }^{40}$

Moreover, the grand Midrash made other references to God's image/likeness. Explaining Genesis 2:18, the Midrash ${ }^{41}$ stated that without female the likeness (הדמות) would be reduced which implies that the likeness referred to in Genesis 1:26-27 posited that humankind was created as male and female. Consequently, the full likeness could be predicated only of humankind defined as both male and female. ${ }^{42}$ Besides, it transpires that in the Midrash the terms 'image' (צלם) and 'likeness' (דמות) were employed as synonyms.

Commenting upon Genesis 9:6, the grand Midrash ${ }^{43}$ presented the idea which was also reflected in the Babylonian Talmud. ${ }^{44}$ The image (identical with the likeness) was understood as God's collective representation in the world assigned to humankind. Thus, God created the human race to serve as his image in the world, namely, to represent him in the world. Therefore, by taking human life or by refusing to procreate, the image would

37 Ibidem, 16r-16v [VIII, 11 (Genesis 1:27)]. Ibidem, 30r [XIV, 3 (Genesis 2:7)].

38 Therefore, the ancient Jewish tradition occasionally spoke of humankind as created in the image of angels but this was a mental shortcut. "מדרש רבה ספר שמות," ספר מדרש רבות על התורה (Leipzig: Wienbrack, 1864), 251 [XXX (Exodus 22:1)]. Adolf Brüll, (ed.), Das samaritanische Targum zum Pentateuch (Frankfurt am Main: Erras, 1875), 10 [Genesis 9:6].

39 Philo of Alexandria also noted that human body, which belonged to the material, visible world, was mortal, while the incorporeal dimension of human beings (called rational soul or mind), which reflected the ideal, invisible world, was immortal. Philo Alexandrinus, "De opificio mundi," 46-47 [46, 134-135]. 
decrease. Consequently, actions which expand or facilitate life, enhance the image, whereas actions, which terminate or suppress life, diminish the image. Clearly, the early Rabbinic tradition affirmed the human body as a part of God's design and recognised it as belonging to the image of God. ${ }^{45}$ In the early Rabbinic tradition this image denoted, on the one hand, the tangible and intangible features which God imprinted on human beings, and on the other hand, the status and function of humankind that in its material (body) and immaterial (soul/spirit) aspects represented God in the world, namely, acted as the image of God in the world.

Such an approach to the image as to the intangible and tangible imprint left by God on humankind in its entirety corresponded to the Talmudic assertion ${ }^{46}$ that the value of individual life ought to be the same as that of the community or even the same as that of whole humankind. Discussing this issue, the Babylonian Talmud ${ }^{47}$ noticed that although the same image, which was imprinted by God on Adam, was also imprinted upon all subsequent generations of human beings, every single human being was unique and should be treated this way. Thus, both the unity and the diversity of the human race were duly acknowledged as a part of God's perfect design.

The ancient Jewish tradition treated Genesis 1:26 with caution and ventured to bring together two propositions which otherwise might be set against one another. On the one hand, God created the world through his Wisdom identical with his Word/Torah, and God could consult his heavenly court, more specifically, his angels, while creating humankind, and he might engage them as his proxies and agents, while creating human beings. On the other hand, God was the sole Creator of the universe so that the act of creation was his work, not that of angels. Therefore, any independent non-divine activity in or contribution to the act of creation was denied. God was to be affirmed as the only Maker of the world with no partner (שותף) in the work of creation. ${ }^{48}$ Actually, the idea of more than one divine power or authority (רשות) involved in the act of creation was condemned in the ancient Jewish literature ${ }^{49}$ and it was characteristic of the Gnostic tendencies penetrating both Judaism and Christianity in that period. ${ }^{50}$

Balancing these two propositions was not an easy task. For instance, the grand Midrash $^{51}$ reported that in Genesis 1:26 God might consult pre-existing souls of the righteous and the possibility of such a consultation was illustrated with 1 Chronicles 4:23 which refers to workers (היוצרים) staying with a king and working for him. These workers

45 " 454 [XXXIV (Leviticus 25:39)]. Alon Goshen Gottstein, “The Body as Image of God in Rabbinic Literature," Harvard Theological Review 87, no. 2, 1994:171-195.

8 Ibidem, 38r [no. 38a]. "ספרש רבה על התורה in 1v [I, 4 (Genesis 1:1)]. Ibidem, 7r [III, 11 (Genesis 1:5)].

49 "תלמוד בבלי "תגיגה, vol. 6 (Warsaw: Orgelbrand, 1860), 15r [no. 15a].

50 Robert GT Edwards, "Clement of Alexandria's Anti-Valentinian Interpretation of Gen. 1:26-27," Zeitschrift für antikes Christentum 18, no. 3, 2014:365-389. Moriz Friedländer, Der vorchristliche jüdische Gnostizismus (Göttingen: Vandenhoeck and Ruprecht, 1898). Heinrich Graetz, Gnostizismus und Judentum (Krotoschin: Monasch, 1846). Robert Travers Herford, Christianity in Talmud and Midrash (London: Williams and Norgate, 1903), 261-266 [I, B, ii]. Ibidem, 291-303 [I, B, iii]. Larry W Hurtado, "First-Century Jewish Monotheism," Journal for the Study of the New Testament 71, 1998:3-26. Adiel Schremer, "Midrash, Theology, and History: Two Powers in Heaven Revisited," Journal for the Study of Judaism 39, 2008:230-254. Alan F Segal, Two Powers in Heaven: Early Rabbinic Reports about Christianity and Gnosticism (Leiden: Brill, 1977). Gedaliahu G Stroumsa, "Form(s) of God: Some Notes on Metatron and Christ," Harvard Theological Review 76, no. 3, 1983:269-288.

51 "ספר בראשית,", in 15v [VIII, 6 (Genesis 1:26)]. 
acted as the king's agents and assistants. Moreover, the Midrash juxtaposed Hebrew יציוצרים, which was derived from the root, with the statement, that God made (וייצר) [the same root יצר] human beings, from Genesis 2:7. Since such an illustration, in which God was compared to an earthly king, while God's counsellors were compared to the king's workers, might imply that souls of the righteous were not only God's counsellors but also 'makers' (היוצרים) of humankind, the Midrash clarified that God (הקב"ה) only consulted them (נמלך) and that he himself created the world (וברא את העולם). Thus, theological limitations were placed on the comparison employed in the Midrash in order to uphold both propositions simultaneously.

The grand Midrash ${ }^{52}$ interpreted the plural form (ידעי) in Genesis 3:5 in the light of the singular form (ידע), of which אלהים was the subject in the same verse, in order to rule out any interpretation undermining God's absolute unity. The Pirke ${ }^{53}$ attributed to Rabbi Eliezer ${ }^{54}$ offered an interesting exposition of the phrase כאלהים ידעי טוב ורע Genesis 3:5. Accordingly, אלהים in that phrase denoted true God, while the knowledge of good and evil was construed as the ability to do good and evil. Thus, the Pirke argued that the serpent tried to convince Eve that by eating the fruit, she could "be like God", namely, could acquire God's power to create and to destroy, to bring to life and to terminate life.

As regards Genesis 3:22 (כאחד ממנו), the grand Midrash ${ }^{55}$ listed three possible interpretations of that phrase. Firstly, אחד ממנו could refer to God cum his holy retinue.

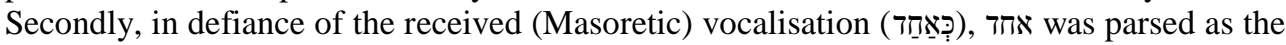
absolute state, while ממנו was parsed as singular (literally: "from him", figuratively: "by himself, on his own"). Consequently, אחד was harnessed to the infinitive (לדעת) which was said to be modified by ממנו. All of this was supposed to produce the following meaning: "Adam became like the one who would know, namely, choose between good and evil by himself". Although the final rendition made sense in the context of the narrative, this reasoning was untenable in grammatical terms because אחד ממנו must be viewed as the partitive phrase ("one of us") and the syntax of Genesis 3:22 would not allow the preposition with the pronominal suffix (ממנו) to modify the infinitive (לדעת) instead of אחד. Thirdly, the grand Midrash epitomised the interpretation recorded in the Targum Onkelos and in the Targum Pseudo-Jonathan. According to this reading, owing to his knowledge of good and evil, Adam became unique in the world in the same way as God was unique in heaven. In other words, by acquiring the knowledge of good and evil, Adam became Godlike because he ultimately possessed the knowledge which was previously reserved for God. In addition, the Yalkut Shimoni ${ }^{56}$ maintained that according to Genesis 3:22, Adam became like one of the angels ministering in front of God and endowed with the knowledge of good and evil.

The plural forms occurring in Genesis 1:26; 3:5 and 3:22 were examined in the Babylonian Talmud. In the case of Genesis 1:26, the tractate Sanhedrin ${ }^{57}$ suggested that God said "let us make [...]" to his heavenly court, and it highlighted God's unity based on the fact that in Genesis 1:27 אלהים was the subject of the singular form of the verb (ויברא). Thus, in Genesis 1:26 God contemplated and announced his intention of creating human-

\footnotetext{
Ibidem, 39r [XIX, 5 (Genesis 3:5)].

53 Pirke Eliezer (פרקי אליעזר) should not be confused with Pirke Avot (פרקי אברות).

54 ספר פרקי רבי אליעזר, 19 [XIII, 12].

55 "מדרש רבה על התורה in, 44r-44v [XXI, 1-5 (Genesis 3:22)].

56 "ילקוט בראשית,"סראשית,", 15r [no. 34 (Genesis 3:22)].

57 “" 5 "
} 
kind in the presence of his angels, whereas Genesis 1:27 reported that God's action had been accomplished. Since God said "let us make [...]" to the angels, "our image", in which humankind was created according to Genesis 1:26, was interpreted as the image both of God and of his angels. Consequently, the image denoted the features which were shared both by God and by the angels.

The tractate Megillah ${ }^{58}$ and the minor tractate of the Babylonian Talmud called Sofrim ${ }^{59}$ implied that in Genesis 1:26 נעשה (let us make) should be interpreted as if God was the sole Maker (אעשה) [I will make]. In the case of Genesis 3:5, Sofrim ${ }^{60}$ stated that the first אלהים was divine, namely, denoted true God, whereas the second one (כאלהים ידעי) was non-divine, yet no further specification was provided.

\section{Mediaeval Jewish Exegesis}

The early Jewish reception of the plural forms in Genesis 1:26, 3:5 and 3:22 defined the parameters of the subsequent Jewish interpretation of these phenomena. Explanations found in the Targumim and in the Midrashic and Talmudic literature were denounced as Jewish by the early church fathers. Justin ${ }^{61}$ recapitulated and disapproved of several interpretations of the plural forms in Genesis 1:26, 3:22. These interpretations did not support the Christian trinitarian reading of such plural forms and were therefore rejected by Justin. Since Justin's account presented the mainstream Jewish positions circulating in the 2nd century accurately, it is relevant to the present research. ${ }^{62}$

Consequently, Justin could not accept that God would say "let us make [...]" to himself, while deliberating and getting down to work. The proposition, that God said "let us make [...]" to the angels, engaging them in the work of creation as his agents, was also rebutted by Justin who asserted that even the human body could not be produced by the angels. Actually, the idea that the angels, who were defined as God's proxies and who could also be conceptualised as $\lambda$ ó $\gamma \delta \varsigma$, created the material world including human corporeality, would be acceptable to Philo and could be argued from his writings. ${ }^{63}$ Furthermore, Justin fended off the interpretation according to which God addressed classical elements ( $\left.\sigma \tau 0 \mathrm{\chi} \chi \varepsilon_{i} \alpha\right)$, such as earth, out of which the human body was created, when he said "let us make [...]". This interpretation implied that God referred to the basic material elements, which had already been created by him, and that God used them to fashion the corporeal dimension of human beings. Thus, Justin epitomised the fundamental Jewish interpretations which must have been circulating and widespread in his lifetime. In fact, his own distinctively Christian exposition rested on the Jewish tradition, though clearly contravening the tenets of Judaism. Justin exploited the concept of divine oopía (as typified by the LXX version of Proverbs 3:19) with which God conversed in the act of creation and through which God created the

“תלמוד בבלי iסריל,, vol. 5 (Warsaw: Orgelbrand, 1860), 9r [no. 9a].

"תלמוד בבלי in, vol. 13, 48v [I, VIII, 5].

Ibidem, 50v [IV, 3].

61 Justinus, "Dialogus cum Tryphone Judaeo," in Patrologiae cursus completus: Series Graeca, vol. 6, (ed.) J-P Migne (Paris: Migne, 1857), 617-620 [\$ 62].

62 Gregory T Armstrong, Die Genesis in der alten Kirche: Die drei Kirchenväter (Tübingen: Mohr, 1962). Bogdan G Bucur, "Justin Martyr's Exegesis of Biblical Theophanies and the Parting of the Ways between Christianity and Judaism," Theological Studies 75/1, 2014:34-51. Friedländer, "Justins Dialog mit dem Juden Tryphon," in Patristische und Talmudische Studien (Vienna: Hölder, 1878), 80-148 [III].

Erwin R Goodenough, The Theology of Justin Martyr (Jena: Biedermann, 1923). Robert McLachlan Wilson, "The Early History of the Exegesis of Gen. 1:26," Studia Patristica 1, 1957:420-437.

63 See the footnote no. 2 in the present article. 
universe, according to the Jewish tradition. Contrary to the Rabbinic consensus, Justin in-

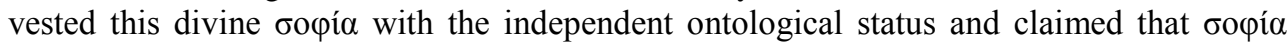
manifested itself in and through Jesus to such an extent that God's wisdom could be embodied in Jesus and identified with Jesus.

Saadia Gaon (סעדיה גאון) expounded on Genesis 1:26-2764 as well as Genesis 3:5 and 3:22. ${ }^{65}$ In his opinion, the plural forms in Genesis 1:26 implied no plurality on the Creator's side but rather emphasised the majesty in a way which was typical of the Hebrew language. Thus, the plural in such expressions as "let us make" (נפשה ) (נפעל) did not have to render the subject plural. To illustrate his point, Saadia referred to Numbers 22:6, ${ }^{66}$ Judges 13:15 ${ }^{67}$ and Daniel 2:36 ${ }^{68}$ where in the direct speech the singular subject applied plural forms to itself very naturally.

Furthermore, Saadia avowed that humankind was created not by angels but rather by the LORD in his image which, for Saadia, did not indicate any corporeal resemblance between God and human beings. Rather, God created humankind in his image in the sense that he recognised and authenticated the dignity and significance of human beings as his creatures and declared them to be his most treasured possession. Consequently, by creating humankind in his image, God owned up to his perfect and beloved design. Saadia equated the image (referred to in Genesis 1:26-27) with the form or shape (צורה) and pointed out that although there were many different shapes in the world, God encompassed all of them. Therefore, when God acclaimed one of the shapes as his own, he acknowledged the unique and unprecedented status of this shape in his eyes. According to Saadia, humankind was the shape favoured by God as his image. In Genesis 3:5 Saadia interpreted אלהים in the phrase כאלהים ידעי טוב ורע as angels ${ }^{69}$ and translated it as angels in his Arabic rendition of the Pentateuch. ${ }^{70}$ Besides, Saadia explicated God's statement in Genesis 3:22 as follows: "Behold, Adam has already been made like one of us [endowed] with the knowledge of good and evil". ${ }^{71}$

Rashi's (רשי") treatment of the plural forms in the aforementioned passages did not offer any coherent strategy of interpretation but rather relied on the Targumic and Midrashic solutions. ${ }^{72}$ Thus, on the one hand Rashi followed a mental shortcut according to which humankind was created in the image of angels, on the other hand, he affirmed that the image, in which human beings were made, was that of their Creator because God himself created humankind as alluded to in Psalm 139:5. In Rashi's opinion, God was so humble that he would regularly consult the heavenly court (more specifically, the angels) surrounding him as exemplified by 1 Kings 22:19 and Daniel 4:14/17. Rashi argued that

64 Saadia Gaon, ספר האמונות והדעות, trans. Judah ibn Tibbon [יהודה אבן תיבון] (Jozefow: 1885), 93-94 [II, 6]. Ibidem, 96 [II, 9]. Ibidem, 147 [V, 8].

65 Saadia Gaon, "בראשית," פירוש על התורה ועל נ"ך (London: Gad, 1959-1960), 10 [Genesis 3:5, 3:22].

66 "Come now therefore, I pray thee, curse me this people; for they are too mighty for me; peradventure I shall prevail, that we may smite them [נכה], and that I may drive them out of the land [...]" (JPS).

67 "And Manoah said unto the angel of the LORD: >I pray thee, let us detain [נעצרה] thee, that we may make ready [ונעשה] a kid [goat] for thee<" (JPS).

68 "[Daniel answered before the king, and said (Daniel 2:27):] This is the dream; and we will tell [נאמר] the interpretation thereof before the king" (JPS).

69 Saadia Gaon, "בראשית," 10 [Genesis 3:5].

70 Saadia Gaon, "Version Arabe du Pentateuque," in CEuvres complètes, vol. 1, (ed.) and trans. Joseph Derenbourg (Paris: Leroux, 1893), 8 [Genesis 3:5].

71 Saadia Gaon, "בראשית," 10 [Genesis 3:22].

72 Berliner, (ed.), Raschi: Der Kommentar des Salomo b. Isak über den Pentateuch (Frankfurt am Main: Kauffmann, 1905), 4 [Genesis 1:26-27]. Ibidem, 7 [Genesis 3:5]. Ibidem, 9 [Genesis 3:22]. 
God indeed consulted his heavenly court and therefore he said to his angels "let us make [...]", yet no one assisted God in the work of creation because the LORD alone created humankind. Furthermore, Rashi admitted that God's exemplary humility might be misperceived as if the superior (i.e. God) needed to win inferiors' (i.e. angels') approval or permission to take any action. Consequently, God addressed the angels by saying to them "let us make [...]" but God did not invite them to join him in the work of creation which in the light of Genesis 1:27a (ויברא אלהים את האדם בצלמו) was performed by God alone, not by multiple agents (ויבראו).

Rashi's interpretation of Genesis 3:5 was equivocal because in his view, to become "like אלהים knowing good and evil" meant to become "like makers of the world". This might suggest the emphatic reading of אלהים in that verse which could be traced back to the Pirke attributed to Rabbi Eliezer. ${ }^{73}$ As regards Genesis 3:22, Rashi paraphrased the Targum Pseudo-Jonathan ${ }^{74}$ and wrote that human beings were unique among earthly (visible) beings just as God was unique among heavenly (invisible) beings. Moreover, Rashi clarified that the unique status of humankind among other earthly creatures consisted in the knowledge of good and evil which was acquired by human beings but which was alien to animals. However, it unclear whether God's unique status consisted in the same knowledge of good and evil as obtained by human beings (because of their consummation of the fruit) or was due to the fact that God was the sole Creator of all visible and invisible beings.

Commenting upon Genesis 1:26-27, Samuel ben Meir (רשב"ם) (רשב $^{75}$ maintained that God said "let us make [...]" to his angels in the same way as he consulted his heavenly court in 1 Kings 22:19-22 and in Job 1:6. Rashbam pointed out that in Isaiah 6:8 the LORD spoke of himself both in the singular (אשלח) and in the plural (לנו) to highlight his majesty. In Rashbam's opinion, human beings were created in the image of angels and the likeness, which was imparted to humankind in the act of creation, equipped human beings with the wisdom (חכמה) which differentiated them from animals. It seems that since the proposition that human beings were created in the image of angels, did not conform to Genesis 1:27a (בצלמו), Rashbam resorted to the Platonising interpretation according to which a human being was created "in his/her own [i.e. human] image", namely, in line with the incorporeal, abstract idea of humankind which mirrored the angelic world.

In his commentary on the Book of Genesis Abraham ibn Ezra (אברהם אבן עזרא) dealt with theological, exegetical and grammatical questions. In theological terms, Abraham ibn Ezra opined that God said "let us make [...]" to the angels and that human beings were created by God in the image of angels. In his view, the plural forms occurring in Genesis 1:26 and in Genesis 11:7 (ונבלה indicated that the LORD addressed his angels. Therefore, according to Abraham ibn Ezra, כאלהים ידעי טוב ורע in מלהים (Genesis 3:5) and (Genesis 3:22) denoted God along with his angels. Besides, Abraham ibn Ezra surmised that the LORD's statement in Genesis 3:22 might be God's account of what Adam aspired to be, as a result of his consummation of the fruit, given that Adam took the serpent's promise (Genesis 3:5) at face value.

\footnotetext{
73 ספר פרקי רבי אליעזר, 19 [XIII, 12].

74 “Targum [Pseudo-]Jonathan," 7 [Genesis 3:22]. Clarke, (ed.), Targum Pseudo-Jonathan of the Pentateuch, 4 [Genesis 3:22].

75 Samuel ben Meir, "פירוש התורה in, (ed.) David Rosin (Breslau: שאטטלענדער, 1881-1882), 8 [Genesis 1:26-27].

76 Abraham ibn Ezra, "פפר בראשית," מקראות גדולות ספר בראשית (New York: 1970-1971), 26-30 [Genesis 1:26-27]. Ibidem, 50 [Genesis 3:5]. Ibidem, 61 [Genesis 3:22].
} 
Abraham ibn Ezra contended that humankind was created by God, not by angels, and that humankind mirrored the glory of its Creator in the sense that the vitality of the highest (whence immaterial and immortal) dimension of human soul (נשמת האדם העליונה) reflected the existence of God. Consequently, this highest incorporeal and immortal dimension of human soul, which originated from God and which was rooted in God, filled the human body in the same way as God, who had no flesh, filled the universe. From Abraham's perspective, the assertion, that only the highest dimension of the human soul participated in the spiritual (angelic) world, granted that this dimension was created in the image of that intangible sphere, did not discredit human corporeality because the human soul dwelt in the human body which was affirmed and valued as the microcosm (עולם קטן). According to Abraham ibn Ezra, God began his work of creation with the intangible (including angels and the highest dimension of the human soul created in the image of the angelic sphere), which could be denominated as the macrocosm (עולם גדול), while he completed his work of creation by engendering the material world inclusive of the human body which was the very microcosm. Thus, by virtue of this divine parentage of human beings, the Scriptures spoke of God's glory revealed as "human resemblance" (Ezekiel 1:26). Nonetheless, based on Isaiah 40:25, Abraham ibn Ezra was convinced that the likeness or image (דמות) of God could never be understood as a sort of copy external to the original, and therefore, he argued that humankind could not be created in the image of God alone.

Simultaneously, Abraham ibn Ezra rejected the Platonising interpretation according to which the pronominal suffix (1) צלם 1 (בצלמו) in Genesis 1:27a) referred to a human being ("God made a human being in the image of a human being") because such a reading posited that there was the image of a human being, the idea of humankind, philosophically speaking, before human beings had been created by God. The proposition that human beings were created by God in line with the eternal abstract idea of humankind, was unpalatable to Abraham ibn Ezra who claimed that in the context of Genesis 1:27 the pronominal suffix (ו) could not stand for and that such an interpretation could not explain the plural suffixes in Genesis 1:26 (כדמותנו, to be precise) in the same way.

Furthermore, the interpretation of the pronominal suffix (1) צל ולם 1: Genesis 1:27a as self-referential was related to the alternative parsing of בצלם אלהים in Genesis 1:27b, 9:6b and of בדמות אלהים in Genesis 5:1 because if the suffix (ו) צלם in Genesis 1:27a did not

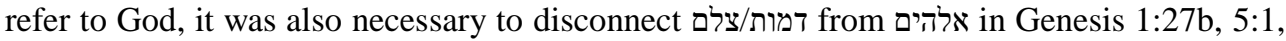
9:6b. Abraham ibn Ezra did not espouse this reasoning either. According to the alternative parsing, בצלם אלהים in Genesis 1:27b, 9:6b and בדמות אלהים in Genesis 5:1 should not be construed as the construct chain but rather דמות/צלם (אלם ought to be viewed as the absolute state ("in/as the image/likeness God created a human being [...]") provided that in the case of

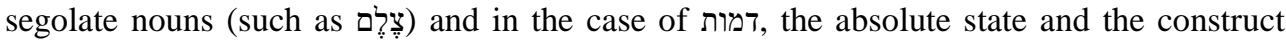
state were identical. Nonetheless, such a reading would not comply with the Masoretic

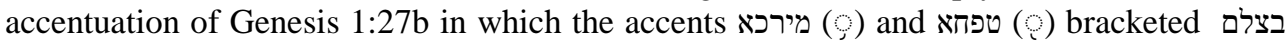
אלהים 5:1. Undoubtedly, this fact lent credence to the interpretation of בדמות אלהים as the construct chain.

Consequently, Abraham ibn Ezra disregarded the interpretation of צלם in Genesis 1:27b, 9:6b and of דמות in Genesis 5:1 as the absolute state, for three reasons: Firstly, such a reading would break the parallelism between Genesis 1:27a and Genesis 1:27b by virtue of

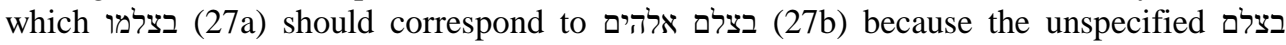
could not be parallel to the specified בצלמו. Secondly, the statement that "God created a 
human being in/as the image/likeness", did not disclose which or whose image/likeness was referred to and would thus be unintelligible.

Thirdly, such an interpretation would undo the moral argumentation in Genesis 9:6a which was based on (כי) Genesis 9:6b; because if צלם in Genesis 9:6b was in the absolute state, this passage only communicated that God created a human being as/in a certain shape or form. For Abraham ibn Ezra, it was obvious that every creature had its own image (shape, form) which, however, incurred no moral obligations. In other words, the moral admonition articulated in Genesis 9:6a could not be caused by the fact that humankind had some shape (form) in the same way as every object would have some shape (form), but must arise rather from the unique and privileged status of human beings in God's eyes.

Abraham ibn Ezra also reported and dismissed the claim that the prepositional phrase "in our image and in our likeness" (Genesis 1:26) was uttered by Moses who described the act of creation from his own, human perspective ("in our image, scilicet, in the image of us, human beings, like me, Moses"). Such reasoning would run counter to all the passages which mentioned "the image of God".

In exegetical terms, Abraham ibn Ezra recapitulated Saadia Gaon's interpretation of Genesis 1:26-27 which could be found in ספפר האמונות והדעות) According to Abraham's recollection, Saadia construed the image as the wisdom (חכמה) and the ability to govern the world (ממשלה), which the Creator bestowed upon humankind, and he assumed that this image was rooted in God for the sake of the splendour of human beings as God's creatures. Consequently, through the concept of human beings as created in God's image, the LORD could seal his possession of humankind. Similarly, although the whole earth belonged to the LORD (Psalm 24:1), the land of Israel was designated as his own (Ezekiel 36:20) in order to stress God's unique ties with the land which he promised to his people.

Furthermore, Abraham ibn Ezra recalled that according to Saadia, the plural forms in Genesis 1:26 might be the plural of majesty which was customary for earthly rulers and which could be used in the Tanakh to narrate God's actions. Abraham ibn Ezra did not object to applying the plural of majesty to narratives about God because he asserted that the Scriptures were written by human authors in the human language so that human beings could understand the message conveyed by these sacred texts. Thus, it was natural for Abraham ibn Ezra that human beings would describe and speak of any reality, inclusive of God, using human expressions because only such expressions were known and accessible to human beings. Therefore, as Abraham ibn Ezra noted, ${ }^{78}$ the Hebrew Bible resorted to anthropomorphism not only with reference to God but also with reference to inanimate objects as exemplified by Numbers $13: 29,{ }^{79} 16: 30^{80}$ and by Proverbs 8:26. ${ }^{81}$ Given his concept of revelation, Abraham ibn Ezra asserted that the interpretation of the plural forms in Genesis 1:26 as the plural of majesty was permissible, yet debatable because the passages (Genesis 29:27:82 Numbers 22:6 and Daniel 2:36), ${ }^{83}$ which, according to his

77 Saadia Gaon, ספר האמונות והדעות, 93-94 [II, 6].

78 In Saadia's masterpiece there is a long section on biblical anthropomorphisms concerning both God and creatures. Among many passages listed by Saadia we can also find the examples which were later cited by Abraham ibn Ezra. Saadia Gaon, ספר האמונות והדעות, 96-98 [II, 10].

79 "[...] and along by the side [literally: hand (יד)] of the Jordan" (JPS).

80 "But if the LORD make a new thing, and the ground open her mouth [פיה], and swallow them up [...]" (JPS).

81 "While as yet He had not made the earth, nor the fields, nor the beginning [literally: head (וראש)] of the dust of the world" (JPS).

82 "[And Laban said (Genesis 29:26):] [...] Fulfil the week of this one, and we will give [ונתנה] thee other also for the service which thou shalt serve with me [עמדי] yet seven other years" (JPS). 
recollection, Saadia Gaon had adduced as proof of the plural of majesty occurring in the Tanakh, were problematised by Abraham ibn Ezra who parsed and explained them differently.

In grammatical terms, Abraham ibn Ezra recalled that some expositors ${ }^{84}$ recognised נעשה in Genesis 1:26 as the niphal participle akin to נעשה from Nehemiah 5:18. ${ }^{85}$ Although the same vocalised form (נָּעָשֶׁה) could be parsed either as the qal imperfect ("let us make [human]") or as the niphal participle ("let [human] be made"), Abraham ibn Ezra preferred the former interpretation (i.e. qal imperfect) in the light of the context. Furthermore,

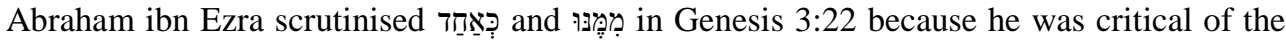
Targumim which explicated these phrases in a peculiar way.

Abraham ibn Ezra ascertained that in the Hebrew Scriptures כאחד played two different syntactical roles which effected two different vocalisations. On the one hand, in אחד was in the construct state (as demonstrated by the vocalisation), functioned as the partitive phrase ("as/like one of [...]") which was bound to another noun or pronoun either directly or indirectly, that is, by means of a preposition (e.g. מן). ${ }^{86}$ Therefore, the

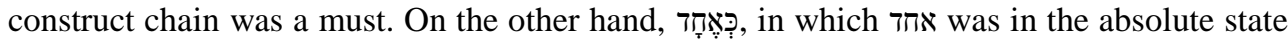
(as evidenced by the vocalisation), acted as the adverbial phrase denoting "together, totally or at once" and it was not a part of any construct chain. ${ }^{87}$ Actually, the Septuagint ${ }^{88}$ and the Targum $^{89}$ always translated כְָָָּ adverbially. Therefore, Abraham ibn Ezra did not accept the Targumic approach to Genesis 3:22 and doubted whether in the context of that verse the prepositional phrase כאחד could denote 'unique'. Rather, he advocated the following rendition: "Adam became like one of us to know good and evil".

As regards מִִ Aִ Abraham ibn Ezra observed that this form could be parsed either as singular or as plural, depending on the context. In Genesis 3:22 the partitive phrase required a group, to which אחד could belong, and therefore, it entailed the plural parsing of

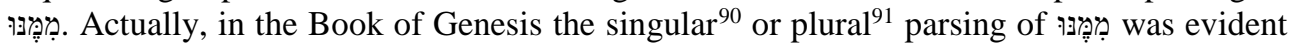
from the context and identified unanimously by the Septuagint ${ }^{92}$ and by the Targum

83 This passage was classified as the plural of majesty by Moses ibn Gikatilla (משה אבן גקטילה), according to Abraham ibn Ezra.

84 It is debatable whether such a view was recorded in the grand Midrash on the Book of Genesis. "ספר בראשר,", in מדרש רבה על התורה, 15v [VIII, 5 (Genesis 1:26)]: "כבר נעשה אדם [...]".

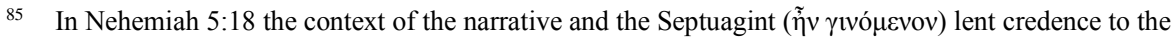
interpretation of נעשה as niphal. Swete, (ed.), The Old Testament in Greek according to the Septuagint, vol. 2 (Cambridge: Cambridge University Press, 1907), 191 [Nehemiah 5:18].

86 See Genesis 3:22, 49:16; Judges 16:7, 16:11, 17:11; 1 Samuel 17:36; 2 Samuel 2:18, 9:11, 13:13; 2 Chronicles 18:12; Ezekiel 48:8; Obadiah 1:11.

87 See 2 Chronicles 5:13; Ezra 2:64, 3:9, 6:20; Nehemiah 7:66; Ecclesiastes 11:6; Isaiah 65:25.

88 Swete, (ed.), The Old Testament, vol. 2, 67 [2 Chronicles 5:13]. Ibidem, 165 [Ezra 2:64]. Ibidem, 166 [Ezra 3:9]. Ibidem, 172 [Ezra 6:20]. Ibidem, 196 [Nehemiah 7:66]. Ibidem, 503 [Ecclesiastes 11:6]. Swete, (ed.), The Old Testament in Greek according to the Septuagint, vol. 3 (Cambridge: Cambridge University Press, 1894), 220 [Isaiah 65:25].

89 "שניידמעסער (Lublin, [s. a.]), 213 [2 Chronicles 5:13]. "Targum,", in in Biblia sacra polyglotta, vol. 3, 424 [Ecclesiastes 11:6]. Paul de Lagarde, (ed.), Prophetae chaldaice (Leipzig: Teubner, 1872), 290 [Isaiah 65:25].

90 See Genesis 2:17, 3:3, 3:5, 3:11, 3:17, 48:19.

91 See Genesis 23:6, 26:16.

92 Swete, (ed.), The Old Testament, vol. 1, 4 [Genesis 2:17]. Ibidem, 4 [Genesis 3:3]. Ibidem, 4 [Genesis 3:5]. Ibidem, 5 [Genesis 3:11]. Ibidem, 5 [Genesis 3:17]. Ibidem, 36 [Genesis 23:6]. Ibidem, 45 [Genesis 26:16]. Ibidem, 98 [Genesis 48:19]. 
Onkelos. ${ }^{93}$ Moreover, Abraham ibn Ezra disagreed with the suggestion that the prepositional phrase (interpreted as singular [“on his own, by himself”]) could modify the infinitive כאחד instead of (taken for the absolute state). Thus, he rejected the second interpretation of Genesis 3:22 recorded in the grand Midrash. ${ }^{94}$

Maimonides (רמב"ם) (רמבם $^{95}$ did not peruse the plural forms in Genesis 1:26 but rather quoted the explanations found in the tractate Sanhedrin and in the grand Midrash on the Book of Genesis. It seems that following in Philo's footsteps, Maimonides presumed that the human body was produced by angels. In Maimonides' opinion, God created human beings in his image in the sense that the divine intelligence, namely, the intelligence originating from God and common to God and his angels, was imparted to humankind, yet to the exclusion of human corporeality because God had neither flesh nor image (תמונה). ${ }^{96}$ Expounding Genesis 3:5, Maimonides ${ }^{97}$ cited the Targum Onkelos and mentioned that since could signify not only true or false God(s) but also angelic or human agent(s) of power, "the mighty" (רברבין) as the non-divine general meaning of אלוהים would be preferable in the context of Genesis 3:5.

In his commentary on the Book of Genesis David Kimhi (רדיק) forms in Genesis 1:26, 3:5 and 3:22, drawing on the exposition which was handed down to him by his father, Joseph Kimhi (יוסף קמחי). Additionally, David Kimhi summarised the interpretations offered by the grand Midrash on the Book of Genesis.

According to Joseph and David Kimhi, God said "Let us make [...]" towards the basic material elements which were previously created by him and which were endowed by him with natural powers. Thus, the LORD used these elements and powers of his own making to create humankind. Figuratively speaking, God intended to communicate "Let us, namely, me [i.e. God] and you [i.e. the elements cum their powers], carry it out" when he said "Let us make [...]". Consequently, the human body was made by God out of these elements and it was equipped with natural powers. On the other hand, through their immaterial dimension (רוח) human beings resembled angels and reflected the 'upper' (celestial) sphere. In Joseph and David Kimhi's view, ${ }^{99}$ this truth was articulated in Genesis 2:7 where the creation of human beings was depicted as the act of God who united the tangible (therefore, אדם was derived from (נשמה) (אדמה) to enact his design. Although the human body arose from the natural elements and powers, while the immaterial dimension of human beings was engendered by the LORD (Zechariah 12:1) and derived from heaven, it was clear that God was the sole Maker of all humanity because the natural elements and powers, which God employed to create human corporeality, were made by him earlier with the intention of creating the human race as the very climax of all his creative activity.

93 Berliner, (ed.), Targum, vol. 1, 2 [Genesis 2:17]. Ibidem, 3 [Genesis 3:3]. Ibidem, 3 [Genesis 3:5]. Ibidem, 3 [Genesis 3:11]. Ibidem, 3 [Genesis 3:17]. Ibidem, 22 [Genesis 23:6]. Ibidem, 27 [Genesis 26:16]. Ibidem, 56 [Genesis 48:19].

94 מדרש רבה על התורה in, 44r-44v [XXI, 1-5 (Genesis 3:22)].

95 Maimonides, More Nebuchim, vol. 2, trans. Judah ibn Tibbon (Vienna: Schmid, 1828), 12v-14r [II, 6].

96 Maimonides, More Nebuchim, vol. 1, trans. Judah ibn Tibbon (Vienna: Schmid, 1828), 10r [I, 1].

97 Ibidem, 10r [I, 2].

98 In Rashi script: David Kimhi, Kommentar zur Genesis, (ed.) Abraham Ginzburg (Pressburg [Bratislava]: Schmid, 1842), 16r-18v [Genesis 1:26-27]. Ibidem, 31v-32v [Genesis 3:5]. Ibidem, 38v-39r [Genesis 3:22]. In square script: David Kimhi, "פירוש רד"ק, מקראות גדולות חומש בית דוד in, vol. 1 (Lemberg: Balaban, 1909), 4v-6r [Genesis 1:26-27]. Ibidem, 15r [Genesis 3:5]. Ibidem, 17r [Genesis 3:22].

99 Supra. David Kimhi, Kommentar, 11r [Genesis 2:7]. Idem, "פירוש רד"ק,"23r [Genesis 2:7].

100 This is a good example of theological etymology. 
Ultimately, God was the One who designed humankind to act as a bridge between heaven and earth, and to unite the intangible and the tangible.

From Joseph and David Kimhi's perspective, at the same time, God said "Let us make [...]" to the angels because human beings were predestined to take part in the intangible sphere which was common to spiritual (i.e. incorporeal) beings, namely, common to God and his angels. Explaining the concept of the image and likeness encountered in Genesis 1:26-27, Joseph and David Kimhi acknowledged that in the Hebrew Scriptures צמות מלם might signify material (physical) ${ }^{101}$ or immaterial (spiritual) ${ }^{102}$ correspondence (resemblance), yet they placed theological limitations upon the plural pronominal suffixes occurring with צלם ("[our] image”) and ("[our] likeness") in this passage.

In their opinion, the plural form of the suffixes was caused by the plural form of the verb ("Let us make [...]") and it did not indicate that human beings were created in the image (likeness) both of the intangible sphere (common to God and his angels) and of the tangible sphere (videlicet, the basic elements created by God). In fact, the early Jewish tradition acclaimed both human body and human soul as God's image and likeness, ${ }^{103}$ while the grand Midrash on the Book of Genesis implied that the image (likeness), which was God imprinted on humankind, reflected both dimensions and that the image (likeness) was God's in the sense that God was the sole Designer thereof. ${ }^{104}$

To the contrary, Joseph and David Kimhi argued that if God said "Let us make [...]" towards his angels, "our image and our likeness" must denote only the spiritual features shared by God and his angels on the stipulation that although both God and angels were spiritual (incorporeal) beings, God was the Creator, while angels were merely his creatures. Thus, the phrase "in our image and in our likeness" meant that some of these spiritual features were bestowed by God upon human beings in the act of creation. It seems that Joseph and David Kimhi upheld both propositions at the same time, teaching that God said "Let us make [...]", on the one hand, to the basic elements, on the other hand, to his angels, yet only the latter (scilicet the angelic reference) was used to explain the plural suffix on צלם in order to exclude non-spiritual features from the image.

In Joseph and David Kimhi's view, the image and likeness did not consist in any physical correspondence but rather in the intelligence (שכל) with the aid of which (בית העזר) God created humankind and with which (בית כלי) God equipped human beings. For Joseph

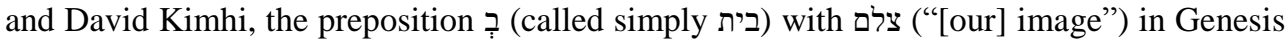
1:26 performed both functions at the same time, namely, implied that God used the divine intelligence (שכל) as his tool (בית העזר) to create humankind and that God furnished human beings with this divine intelligence (בית כלית). In other words, God created the human race through the image defined as certain spiritual features (shared by God and his angels) and God imparted this image (i.e. features in question) to human beings. Consequently, the creation of humankind as both physical and spiritual beings could be perfected and brought to completion. Analysing כדמותנו in Genesis 1:26, Joseph and David Kimhi clarified that the preposition ?ִ conveyed a sense of correspondence which in this instance must be only partial, not full, because human beings participated only in some spiritual features common to God and his angels.

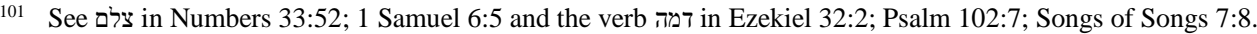

102 See דמות in Ezekiel 1:13.

103 "ספר מדרש רבות על התורה in, 354 [XXXIV (Leviticus 25:39)]. Gottstein, “The Body as Image of God in Rabbinic Literature," 71-195.

104 "מדרש רבה על התורה in, 29v [XIV, 3 (Genesis 2:7)].
} 
In Genesis 3:5 David Kimhi interpreted אלהים as the angels and in Genesis 3:22 he asserted that God said "like one of us" because the LORD referred to himself and to his angels. Likewise, the plural forms in Genesis 1:26 ("Let us make [...]", "in our image and in our likeness") and in Genesis 3:22 might be caused by the fact that God intended to speak for himself and for the angels surrounding him. Furthermore, Radak cited the grand Midrash on Genesis 3:22 and briefed on the vocalisation of כאחד.

The exposition of Genesis 1:26-27 found in David Kimhi's commentary was recapitulated and adopted by Nahmanides (רמב"ן), ${ }^{105}$ who however did not exclude human corporeality from "our image and our likeness". Rather, for Ramban, this phrase communicated that human beings resembled (ידמה) both dimensions given that the human body belonged to the material sphere, while the human spirit (רוח) belonged to the immaterial one. Similarly, Jacob ben Asher (יעקב בן ראש), ${ }^{106}$ who was also called the Master of the Rows (בעל הטורים), explicated "our image and our likeness" as the intentional reference (דומה) to both spheres. Finally, in his long commentary on Genesis 1:26 Hezekiah ben Manoah (חזקיה בן מנוח) ${ }^{107}$ explained that the plural form of the verb might be the plural of majesty as exemplified by Isaiah 6:8 and Daniel 2:36 where the singular subject referred to itself in the plural. Moreover, Hezekiah remarked that the choice of the verb, which in Genesis 1:26 was used in the plural, was not an accident. In his view, the verb was not employed in that verse because it denoted the absolute creative activity which only God could perform. Therefore, Hezekiah averred that in the light of Genesis 1:27 and of Genesis 6:7 only God could be recognised as the Maker of human beings. Consequently, in Genesis 1:26 God employed the plural form of the verb ברא עשה, , עש , in order to invite his agents, presumably, either angels or natural elements/powers, to assist him in carrying out this project. Thus, God used the plural because he spoke on his behalf and on behalf of his associates.

\section{Conclusion}

The mediaeval Jewish tradition, on the one hand, relied on the earlier exposition of the plural forms in Genesis 1:26, 3:5 and 3:22, which occurred in the Targumim and in the Midrashic and Talmudic literature; on the other hand, it enriched and advanced the trajectory of the interpretations accepted within the limits of Judaism. Clearly, Jewish translators and expositors tried to eschew any interpretation which might undermine the absolute unity of the Godhead or diminish the status of God as the sole Creator of the universe, including humankind.

Although Philo did not hesitate to outsource the act of creating the material world, inclusive of human body, to God's agents, in the face of Gnosticism and Christianity, postHellenistic Judaism was cautious about the status and function of instruments or mediators in the act of creation, and it was compelled to vindicate the dignity and value of the tangible sphere, particularly, of human corporeality. From an exegetical perspective, the Jewish reading of these plural forms was rooted in the context of the Hebrew language and in the context of the Hebrew Scriptures. Thus, the use of the plural in Hebrew was studied and

\footnotetext{
105 Nahmanides, "מקראות גדולות ספר בראשית, in, 25-28 [Genesis 1:26-27]. Ibidem, 38-39 [Genesis 2:7].

106 Jacob ben Asher, "פראשית," פירוש הטור על התורה (Warsaw: זיסבערג, 1880), 4r [Genesis 1:26].

107 Hezekiah ben Manoah, "ספר חראשית (Lemberg [Lviv]: Schrenzel, 1859), $4 \mathrm{v}$ [Genesis 1:26].
} 
relevant passages referring to the creation of humankind or containing the appellation in its non-divine denotations were examined.

Finally, the Jewish exegetical tradition in the Middle Ages did not conceal its presuppositions or intentions but rather took pride in its mission, which was to facilitate the understanding of the plural forms in the Tanakh which were potentially pertinent to God. In anthropological terms, Judaism offered an intriguing perspective on human beings as creatures designed to embrace both the tangible and the intangible, to bridge the gulf תיקון עולם as their calling.

\section{BIBLIOGRAPHY}

Abraham ibn Ezra 1970-1971. "ספר בראשית. Now In מקראות גדולות ספר בראשית. Nork: פריעדמאן.

Armstrong, Gregory T 1962. Die Genesis in der alten Kirche: Die drei Kirchenväter. Tübingen: Mohr.

Berliner, Abraham (ed.) 1905. Raschi: Der Kommentar des Salomo b. Isak über den Pentateuch. Frankfurt am Main: Kauffmann.

Berliner, Abraham (ed.) 1884. Targum Onkelos, vol. 1. Berlin: Kauffmann.

Bray, Gerald 1991. "The Significance of God's Image in Man.” Tyndale Bulletin 42/2. "בראשית. 1913. In ספר מדרש תנחומא. Petrikau: צעדערבוים.

Brüll, Adolf (ed.), 1875. Das samaritanische Targum zum Pentateuch. Frankfurt am Main: Erras.

Bucur, Bogdan G 2014. "Justin Martyr's Exegesis of Biblical Theophanies and the Parting of the Ways between Christianity and Judaism." Theological Studies 75/1.

Burnett, Joel S 2001. A Reassessment of Biblical Elohim. Atlanta: Society of Biblical Literature.

Clarke, Ernest George (ed.) 1984. Targum Pseudo-Jonathan of the Pentateuch: Text and Concordance. Hoboken: KTAV.

Clines, David JA 1968. "The Image of God in Man." Tyndale Bulletin 19.

Cook, Johann 1983. “Anti-heretical Traditions in Targum Pseudo-Jonathan.” Journal of Northwest Semitic Languages 11.

Crouch, Carly Lorraine 2010. “Genesis 1:26-7 as a Statement of Humanity's Divine Parentage." Journal of Theological Studies 61/1.

Dahl, NA \& Alan F Segal 1978. "Philo and the Rabbis on the Names of God." Journal for the Study of Judaism 9, no. 1.

De Lagarde, Paul, (ed.), 1872. Prophetae chaldaice. Leipzig: Teubner.

Dillmann, August 1897. Genesis Critically and Exegetically Expounded, vol. 1, trans.

William Black Stevenson. Edinburgh: Clark.

Draffkorn, Anne E 1957. "Ilani/Elohim.” Journal of Biblical Literature 76, no. 3.

Driver, Samuel Rolles 1904. The Book of Genesis with Introduction and Notes. London: Methuen.

Dulkin, Ryan S 2013. “The Triumph of Mercy: An Ethical-Critical Reading of Rabbinic Expansions on the Narrative of Humanity's Creation in Genesis Rabbah 8." Journal of the Society of Christian Ethics 33, no. 1.

Edwards, Robert GT 2014. "Clement of Alexandria's Anti-Valentinian Interpretation of Gen. 1:26-27." Zeitschrift für antikes Christentum 18, no. 3. 
Field, Frederick (ed.),1875. Origenis Hexaplorum quae supersunt: Sive veterum interpretum Graecorum in totum Vetus Testamentum fragmenta, vol. 1. Oxford: Clarendon.

Fossum, Jarl 1985. "Gen. 1:26 and 2:7 in Judaism, Samaritanism and Gnosticism." Journal for the Study of Judaism 16, no. 2.

Friedländer, Moriz 1878. "Justins Dialog mit dem Juden Tryphon.” In Patristische und Talmudische Studien. Vienna: Hölder.

Friedländer, Moriz 1898. Der vorchristliche jüdische Gnostizismus. Göttingen: Vandenhoeck and Ruprecht.

Goodenough, Erwin R 1923. The Theology of Justin Martyr. Jena: Biedermann.

Gordon, Cyrus Herzl 1935. "אלהים in its Reputed Meaning of >Rulers<, > Judges<." Journal of Biblical Literature 54, no. 3.

Gottstein, Alon Goshen 1994. "The Body as Image of God in Rabbinic Literature." Harvard Theological Review 87, no. 2.

Graetz, Heinrich 1846. Gnostizismus und Judentum. Krotoschin: Monasch.

"תלמוד בבלי תגיג, 1860. vol. 6. Warsaw: Orgelbrand.

Harris, Murray J 1984. "The Translation of Elohim in Psalm 45:7-8.” Tyndale Bulletin 35.

Hasel, Gerhard F 1975. "The Meaning of > Let us< in Gn 1:26.” Andrews University Seminary Studies 13, no. 1.

Heiser, Michael S 2001. "Deuteronomy 32:8 and the Sons of God." Bibliotheca Sacra 158, no. 629.

Herford, Robert Travers 1903. Christianity in Talmud and Midrash. London: Williams and Norgate.

Hezekiah ben Manoah 1859. "ספר בראשית." In ספר חזקוני על חמשה חומשי תורה. Lemberg [Lviv]: Schrenzel.

Holmes, Robert \& James Parsons, (ed.), 1827. Vetus Testamentum Graecum cum variis lectionibus, vol. 5. Oxford: Clarendon.

Hurtado, Larry W 1998. "First-Century Jewish Monotheism." Journal for the Study of the New Testament 71.

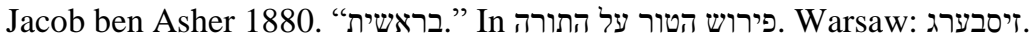

"ילקוט בראשית" 1863. In ספר ילקוט שמעונית. Vilnius: Romm.

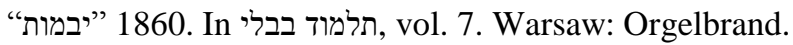

Jehiel, Nathan 1819. Rabbinisch-aramäisch-deutsches Wörterbuch zur Kenntnis des Talmuds, der Targumim und Midraschim, vol. 2, (ed.) Moses Israel Landau. Prague: Scholl.

Joosten, Jan 2007. “A Note on the Text of Deuteronomy 32:8." Vetus Testamentum 57, no. 4.

Justinus 1857. "Dialogus cum Tryphone Judaeo.” In Patrologiae cursus completus: Series Graeca, vol. 6, (ed.) J-P Migne. Paris: Migne.

Keil, Carl Friedrich \& Franz Delitzsch (s.a.). Biblical Commentary on the Old Testament, vol. 1, trans. James Martin. Grand Rapids: Eerdmans.

Kimhi, David 1842. Kommentar zur Genesis, (ed.) Abraham Ginzburg. Pressburg [Bratislava]: Schmid.

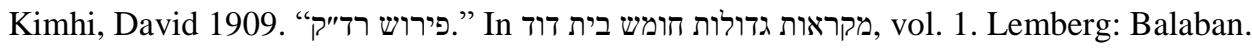

Levy, Jacob 1867. Chaldäisches Wörterbuch über die Targumim und einen grossen Teil des rabbinischen Schrifttums, vol. 1. Leipzig: Baumgärtner. 
Maimonides 1828. More Nebuchim, vol. 1, trans. Judah ibn Tibbon. Vienna: Schmid.

Maimonides 1828. More Nebuchim, vol. 2, trans. Judah ibn Tibbon. Vienna: Schmid.

McKenzie, John L 1948. "The Appellative Use of El and Elohim." The Catholic Biblical Quarterly 10, no. 2.

" 1864. In תלמוד בבלי "מגילה, vol. 5. Warsaw: Orgelbrand.

ספר מדרש רבות על התורה 1864. Leipzig: Wienbrack.

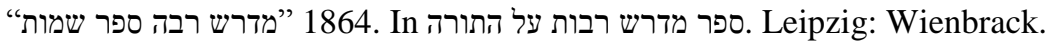

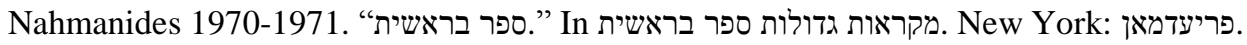

Niehoff, Maren R 2008. "Questions and Answers in Philo and Genesis Rabbah.” Journal for the Study of Judaism 39.

Niskanen, Paul 2009. "The Poetics of Adam: The Creation of אדים in the Image of Journal of Biblical Literature 128, no. 3.

Philo Alexandrinus 1897. "De confusione linguarum.” In Opera quae supersunt, vol. 2, (ed.) Leopold Cohn and Paul Wendland. Berlin: Reimer.

Philo Alexandrinus 1898. "De fuga et inventione.” In Opera quae supersunt, vol. 3, (ed.) Leopold Cohn and Paul Wendland. Berlin: Reimer.

Philo Alexandrinus 1898. "De mutatione nominum.” In Opera quae supersunt, vol. 3, (ed.) Leopold Cohn and Paul Wendland. Berlin: Reimer.

Philo Alexandrinus 1896. "De opificio mundi.” In Opera quae supersunt, vol. 1, (ed.)

Leopold Cohn and Paul Wendland. Berlin: Reimer.

Philo Alexandrinus 1898. "De sominiis liber I.” In Opera quae supersunt, vol. 3, (ed.)

Leopold Cohn and Paul Wendland. Berlin: Reimer.

Philo Alexandrinus 1826. "In Genesi: Sermo I.” In Paralipomena Armena, (ed.) Joannes Baptista Aucher. Venice: Lazari.

Philo Alexandrinus 1896. "Legum allegoriarum liber III.” In Opera quae supersunt, vol. 1, (ed.) Leopold Cohn and Paul Wendland. Berlin: Reimer.

Philo Alexandrinus 1898. "Quis rerum divinarum heres sit." In Opera quae supersunt, vol. 3, (ed.) Leopold Cohn and Paul Wendland. Berlin: Reimer.

Ringgren, Helmer 1974. "אלהים." In Theological Dictionary of the Old Testament, vol. 1, (ed.) Gerhard Johannes Botterweck and Helmer Ringgren, trans. John T Willis. Grand Rapids: Eerdmans.

Saadia Gaon 1959-1960. "בראשית." In Iירוש על התורה ועל נ"ך. London: Gad.

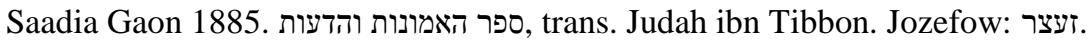

Saadia Gaon 1893. "Version Arabe du Pentateuque.” In Euvres complètes, vol. 1, (ed) and trans. Joseph Derenbourg. Paris: Leroux.

Samuel ben Meir 1881-1882. "בראשית, (פירוש התורה, (ed.) David Rosin. Breslau: שאטטלענדער.

"תנהדרין, 1862. In תלמוד בבלי, 13. Warsaw: Orgelbrand.

Schremer, Adiel 2008. "Midrash, Theology, and History: Two Powers in Heaven

Revisited," Journal for the Study of Judaism 39.

" 1890. In מדרש רבה על התורה. Warsaw: Orgelbrand.

1838. Vilnius: Romm.

Segal, Alan F 1977. Two Powers in Heaven: Early Rabbinic Reports about Christianity and Gnosticism. Leiden: Brill.

"סופרים, 1862. In תלמוד בבלי, vol. 13. Warsaw: Orgelbrand. 
Stroumsa, Gedaliahu G 1983. "Form(s) of God: Some Notes on Metatron and Christ." Harvard Theological Review 76, no. 3.

Swete, Henry Barclay (ed.) 1887. The Old Testament in Greek according to the Septuagint, vol. 1. Cambridge: Cambridge University Press.

Swete, Henry Barclay (ed.) 1907. The Old Testament in Greek according to the Septuagint, vol. 2. Cambridge: Cambridge University Press.

Swete, Henry Barclay (ed.) 1894. The Old Testament in Greek according to the Septuagint, vol. 3. Cambridge: Cambridge University Press.

"s.a. In מקרגום גדולות ספר דברי הימים. Lublin: שניידמעסער.

“Targum” 1656. In Biblia sacra polyglotta, vol. 3, (ed.) Brian Walton. London: Roycroft.

“Targum Hierosolymitanum” 1657. In Biblia sacra polyglotta, vol. 4, (ed.) Brian Walton. London: Roycroft.

“Targum [Pseudo-]Jonathan” 1657. In Biblia sacra polyglotta, vol. 4, (ed.) Brian Walton. London: Roycroft.

"Targum of Palestine" 1862. In The Targums of Onkelos and Jonathan ben Uzziel on the Pentateuch with the Fragments of the Jerusalem Targum: Genesis and Exodus, trans. John Wesley Etheridge. London: Longman.

Von Gall, August (ed.) 1914. Der Hebräische Pentateuch der Samaritaner, vol. 1. Giessen: Töpelmann.

Von Rad, Gerhard 1961. Genesis: A Commentary, trans. John H Marks. Philadelphia: The Westminster Press.

Wardlaw, Terrance Randall 2008. Conceptualising Words for $>$ God $<$ within the Pentateuch: A Cognitive-Semantic Investigation in Literary Context. New York: T\&T Clark.

Wedderburn, AJM 1973. "Philo's >Heavenly Man<." Novum Testamentum 15, no. 4. Welz, Claudia 2011. "Imago Dei: References to the Invisible." Studia Theologica 65.

Wenham, Gordon J 1998. Genesis: 1-15, vol. 1. Dallas: Word.

Westermann, Claus 1984. Genesis 1-11: A Commentary, trans. John J Scullion. Minneapolis: Augsburg Publishing House.

Wilson, Robert McLachlan 1957. "The Early History of the Exegesis of Gen. 1:26.” Studia Patristica 1. 